\author{
Aleksandra Kumala \\ [Uniwersytet Jagielloński] \\ (iD https://orcid.org/0000-0001-9833-3185
}

\title{
Męska homoseksualność obozowa i figura pipla a problem „nieczytalności” na przykładzie relacji Andrzeja Kotarskiego
}

\section{[Male Concentration Camp Homosexuality, the Figure of Pipel and the Issue of 'Unreadability' in Andrzej Kotarski's Testimonies]}

DoI: 10.26774 /wrhm.298

Data wpłynięcia tekstu: 30 sierpnia $2021 \mathrm{r}$.

Data wpłynięcia tekstu po poprawkach: 2 grudnia $2021 \mathrm{r}$.

Data publikacji: 23 grudnia $2021 \mathrm{r}$.

Praca jest oryginalna i nie była nigdzie wcześniej publikowana.

\begin{abstract}
Abstrakt
Artykuł o charakterze case study analizuje treści dotyczące męskiej homoseksualności i figury pipla, pojawiające się w dwóch relacjach złożonych usc Shoah Foundation i Domu Spotkań z Historią/Ośrodkowi KARTA przez Andrzeja Kotarskiego, byłego więźnia nazistowskich obozów koncentracyjnych. Krytycznej refleksji poddane zostają: sposób podjęcia tematów zmarginalizowanych w polskim dyskursie obozowym oraz strategie służące przezwyciężeniu problemów artykulacyjnych. Osadzenie analizy w kontekście badań nad wojenną przemocą (homo)seksualną pozwala wskazać kulturowo-społeczne determinanty, za sprawą których obie relacje pozostają niepełne.
\end{abstract}

\begin{abstract}
The article is a case study analyzing the issues of male homosexuality and the figure of pipel, which appear in two oral testimonies of Andrzej Kotarski - former prisoner of the Nazi concentration camps - given respectively to the usc Shoah Foundation and the History Meetings House/ KARTA Center. The ways of addressing themes marginalized in the Polish concentration camp discourse, as well as the strategies used to overcome articulation problems, are being critically examined. Placing the analysis in the context of wartime (homo) sexual violence makes it possible to point out cultural and social determinants because of which both testimonies remain incomplete.
\end{abstract}

\section{Słowa kluczowe}

relacje homoseksualne, obozy koncentracyjne, pipel

\section{Keywords}

homosexual relations, concentration camps, pipel 
Regularne obcowanie z mówionymi i pisanymi świadectwami osób, które przeżyły II wojnę światową, umożliwia nie tylko „rozpoznanie dominujących schematów narracyjnych relacjonowania różnych zbiorowych doświadczeń wojennych (master narratives)" ${ }^{1}$, w tym doświadczeń związanych z pobytem w obozach koncentracyjnych. Poszukiwanie i interpretowanie treści dotyczących rozmaitych form męskiej homoseksualności obozowej w relacjach byłych polskich więźniów ${ }^{2}$ - zwłaszcza po kilkunastu latach od momentu powstania takich świadectw $^{3}$ - uświadamia istnienie nierozpoznanych obszarów obozowo-pamięciowego dyskursu oraz zmarginalizowanych czy wręcz stabuizowanych tematów. Samo ich podjęcie jest dalece nieoczywiste i rzadko spotykane, przez co stanowi wyzwanie dla wszystkich zaangażowanych w proces osób: opowiadającej, przeprowadzającej wywiad oraz dla tej, która analizuje go po latach.

Niniejszy artykuł został pomyślany jako case study wybranych fragmentów dwóch relacji, złożonych kolejno w 1998 i 2007 r. przez Andrzeja Kotarskiego - byłego więźnia obozów na Majdanku, w Gross-Rosen (Rogoźnica) i Leitmeritz (Litomierzyce). Fragmenty te dotyczą zjawiska obozowych relacji homoseksualnych oraz - centralnej dla namysłu nad nimi, jak również narracji o nich - figury pipla 4 . Mianem tym określano młodych chłopców, którzy - w zamian za jedzenie czy inne korzyści, a nierzadko pod przymusem - świadczyli różnego rodzaju usługi (także o charakterze seksualnym) więźniom zajmującym wyższe pozycje w obozowej hierarchii. Z wielu względów cieszyli się oni złą sławą wśród członków lagrowej

$1 \quad$ P. Filipkowski, Historia mówiona i wojna. Doświadczenie obozu koncentracyjnego w perspektywie narracji biograficznych, Wrocław 2010, s. 32.

2 Tego zadania badawczego, w odniesieniu do polskich więźniów politycznych, podejmuję się w ramach prac nad rozprawą doktorską.

3 Jak stwierdził P. Filipkowski, „Te świadectwa nie przemówią już nigdy same. Trzeba je będzie wydobyć, odczytać, odsłuchać, obejrzeć. A potem zinterpretować, przyoblec w sensy, nadać aktualne znaczenia. To wszystko odbywać się już będzie zawsze pod nieobecność autorów, narratorów, «świadków». I z coraz większym do nich dystansem - biograficznym, czasowym, emocjonalnym, tożsamościowym”; ibidem, s. 8.

4 Słowo to pojawia się w tytule pionierskiego anglojęzycznego artykułu na ten temat (R. Sommer, Pipels: Situational Homosexual Slavery of Young Adolescent Boys in Nazi Concentration Camps, „Lessons and Legacies”, t. 11 (2014), red. H. Earl, K. Schleunes, s. 86-103), widnieje też w anglojęzycznej Wikipedii: https://en.wiktionary.org/wiki/Pipel (dostęp: 20 vi 2021 r.). Rzadkość jego występowania najpewniej wiąże się z niewielką - jak dotąd - ilością akademickich opracowań. W języku polskim zob.: J. Ostrowska, „Panienki”, „szwungi”, "fajfusy”, „laleczki”, [w:] eadem, Oni. Homoseksualiści w czasie II wojny światowej, Warszawa 2021, s. 263-279. 
wspólnoty; widoczny w powojennych wspomnieniach, skrajnie negatywny wizerunek pipli jest wypadkową cech indywidualnych i tych, które przypisywano im jako grupie. Prześledzenie sposobów ujmowania tych fenomenów w ramy jednostkowego doświadczenia ma na celu pokazanie, jak w polu oral history dochodzi do „wydobycia z przeszłości głosów zapomnianych bądź wyciszonych (hidden voices)"5 oraz za pomocą jakich strategii - i z jakim skutkiem - podejmowane są próby wyartykułowania przeżyć odnoszących się jednocześnie do seksualności i nazizmu, a zatem, używając formuły zaproponowanej przez Elizabeth Heineman, „podwójnie niewypowiadalnych (doubly unspeakable)”“. Krytycznej refleksji poddany zostanie również wpływ osoby przeprowadzającej wywiad (w tym fakt (nie)zadawania przez nią określonych pytań) na przebieg rozmowy, oraz ewentualne uszczegółowienia czy rozwinięcia pojawiających się w jej trakcie treści. Te z kolei odczytane zostaną zgodnie ze stworzoną przez Jessicę Lang - tu z konieczności nieco przeformułowaną - koncepcją „nieczytalności” (unreadability)7.

\section{Homoseksualna przemoc i wizerunek pipli. Stan badań}

Tommy J. Curry przekonuje, że niedoboru relacji odnoszących się do homoseksualnych gwałtów czy homoseksualnej przemocy w okresie II wojny światowej, w kryjówkach, gettach czy obozach koncentracyjnych, nie należy traktować jako dowodu na nieistnienie tego rodzaju zjawisk. Jest on raczej konsekwencją powiązanych ze sobą procesów: zrozumiałego oporu świadków przed otwartym poruszaniem tego rodzaju kwestii i środowisk badawczych przed dopytywaniem o nie, a także późniejszej, zachowawczej lektury źródeł, niewystarczająco wrażliwej, bo nie zawsze nastawionej na poszukiwanie treści przełamujących społeczne czy obyczajowe tabu8. W ostatnich latach, także w obrębie Holocaust studies, zaobserwować można jednak znaczącą zmianę strategii i praktyk badawczych: wątki przemocy (homo)seksualnej, podejmowane w pisanych i mówionych relacjach ocalałych, coraz częściej poddaje się wnikliwym analizom, wydobywa ze sfery przemilczeń9.

5 M. Kurkowska-Budzan, Informator, świadek historii, narrator - kilka wątków epistemologicznych i etycznych oral history, „Wrocławski Rocznik Historii Mówionej”, R. 1 (2011), s. 13 .

6 E. Heineman, Sexuality and Nazism: The Doubly Unspeakable?, „Journal of the History of Sexuality", t. 11 (1-2/2002), s. 22-66.

7 Zob.: J. Lang, Textual Silence: Unreadability and the Holocaust, New Brunswick-New Jersey 2017.

8 Por.: T.J. Curry, Thinking through the silence: theorizing the rape of Jewish males during the Holocaust through survivor testimonies, „Holocaust Studies”, nr 1 (2020), s. 1-27.

9 Por.: A. Baldwin, 'And What Happened Next?': Emotions and Sexual Violence in Holocaust Interviews, „Oral History Australia Journal”, nr 41 (2019), s. 32-42; R. Mühlhäuser, 
Jedną z najbardziej emblematycznych i niejednoznacznych figur w uniwersum obozowych relacji homoseksualnych pozostaje wspomniany już pipel. Negatywne konotacje niosła ze sobą nie tylko etymologia tego określenia ${ }^{10}$, lecz także przypisywane tej grupie więźniów (jeszcze w obozach, a następnie w odnoszących się do nich relacjach) cechy: brutalność, deprawacja i - co szczególnie istotne w kontekście niniejszego artykułu - sfeminizowanie ${ }^{11}$. W opublikowanych wspomnieniach z lagrów postaci te określane są przede wszystkim jako potencjalni oprawcy, ochoczo wykorzystujący swą uprzywilejowaną pozycję i niestroniący od przemocy ${ }^{12}$. Niektórzy autorzy wydanych drukiem tekstów wspominają też jednak o realnym zagrożeniu zdrowia i życia tych, którzy nie przystali na propozycję z kategorii „nie do odrzucenia” lub utracili względy obozowego protektora, a także o tym, jakimi metodami zmuszano młodych więźniów do uległości ${ }^{13}$. Znacznie rzadziej piple wprost identyfikowani są jako ofiary seksualnych nadużyć czy handlu żywym towarem ${ }^{14}$.

Jedną z cech decydujących o inności pipli, determinujących ich marginalną pozycję w obozowej wspólnocie, miała być przypisywana im „zniewieściałość”. Z jednej strony, samo zaistnienie (w obozie i w poobozowym świadectwie) mężczyzny-ofiary przemocy o seksualnym charakterze może skutkować rozsadzeniem (czy przynajmniej rozszczelnieniem) społecznych ram pojmowania męskości ${ }^{15}$. Z drugiej, jak stwierdził Adam Jones, „jedną z najbardziej zabójczych ról genderowych jest współcześnie ta «sfeminizowanego» samca („feminized” male) [...], który przyjął kulturową identyfikację z tradycyjnie kobiecymi rolami

Understanding Sexual Violence during the Holocaust: A Reconsideration of Research and Sources, „German History”, t. 39 (1/2020), s. 15-36; D. Głowacka, Sexual Violence against Men and Boys during the Holocaust: A Genealogy of (Not-So-Silent) Silence, "German History”, t. 39 (1/2020), s. 78-99; J. Ostrowska, op. cit., Warszawa 2021.

10 W dialekcie berlińskim der Pipel oznacza zarówno młodego chłopca, jak i penisa, i jest, według Joanny Ostrowskiej, określeniem pogardliwym; zob.: J. Ostrowska, op. cit., s. 266. Więcej na temat alternatywnych/synonimicznych sformułowań oraz fenomenu, do którego się odnoszą, zob.: ibidem; R. Sommer, op. cit., s. 86.

11 Por.: J. Ostrowska, op. cit., s. 264.

12 Por.: W. Zarachowicz, Nas nie pożarły płomienie. Radogoszcz-Gusen, Warszawa 1991, s. 232; J. Zakrzewski, A my żyjemy dalej..., Lublin 1977, s. 71.

13 Zob.: S. Grzesiuk, Pięć lat kacetu, Warszawa 1972, s. 363-365.

14 G. Timofiejew wspomina: „Więc i w obozie odbywał się handel żywym towarem. Ładny, dwunastoletni chłopczyk wpadł w oko blokowemu na kwarantannie. Aliści blokowy pomiarkował «uczucia» i postanowił na chłopaku zarobić. Odżywił go i sprzedał kolegom Niemcom za cenne zawsze w obozie papierosy". Zob.: G. Timofiejew, Człowiekjest nagi, Łódź 1960, s. 121.

Por.: T.J. Curry, op. cit., s. 13. 
i zachowaniami lub któremu ją narzucono"16. Pogarda względem pipli mogła wynikać z przekonania, że przynosili oni ujmę tradycyjnie rozumianej męskości. Dodać w tym miejscu należy, iż ze względu na zwyczajowe łączenie "męskości z władzą/siłą (power), a kobiecości z podatnością per se (vulnerability)" ${ }^{17}$ przemoc seksualna stała się narzędziem „zniewolenia i sfeminizowania ofiary, przy jednoczesnym wzmocnieniu (empowering) sprawcy"18. Feminizację rozumiem więc jako kategorię podwójnie opresyjną: choć sam jej wymiar symboliczny sytuuje pipli na poziomie ofiar (słabszych, więc kobiecych), powodowane nią wykluczenie z męskiej wspólnoty pozbawia ich tego statusu.

Kwestie te są o tyle istotne, że postrzeganie oral history jako dialogicznego procesu zakłada nie tylko interakcję osoby przeprowadzającej wywiad z narratorem, ale również narratora z kulturąa chowanych genderowo, treści i nadawaniu im znaczeń każdorazowo towarzyszy (wpływająca na ich formę lub wręcz je ograniczająca) świadomość społeczno-kulturowych norm determinujących recepcję. Piętno „sfeminizowania” może skutecznie uniemożliwiać ofierze homoseksualnej przemocy nie tylko ekspresję swojej męskości i seksualności, ale także artykulację traumatycznych przeżyće ${ }^{20}$.

Przykład próby przekroczenia tego rodzaju ograniczeń stanowią dwie omawiane w artykule relacje. Pierwsza z nich, datowana na rok $1998^{21}$ i dostępna w formie nagrania wideo, dowodzi, że już wówczas niektórzy badacze i badaczki zdawali sobie sprawę z istnienia fenomenu męskich relacji homoseksualnych w obozach koncentracyjnych. Granicę wypowiadalności, do której w pewnym momencie swojej opowieści dociera Kotarski, kształtują m.in. opisane pokrótce napięcia społeczno-kulturowe czy brak „sprawdzonego” schematu dystrybucji tego typu treści. Konsekwencją jest zastąpienie dobrowolnie poruszonego tematu opowieściami mniej transgresyjnymi i kontrowersyjnymi.

A. Jones, Straight as a Rule: Heteronormativity, Gendercide, and the Noncombatant Male, „Men and Masculinities”, t. 8 (4/2006), s. 353-354. Jeśli nie zaznaczono inaczej, wszystkie tłumaczenia pochodzą od autorki.

É. Féron, Wartime Sexual Violence Against Men. Masculinities and Power in Conflict Zones, Lanham 2018, s. 121. W tekście posługuję się przekładem pojęcia vulnerability zaproponowanym przez Agatę Czarnacką. Por.: Posłowie od tłumaczki, [w:] J. Butler, Ramy wojny. Kiedy życie jest godne opłakiwania?, tłum. A. Czarnacka, Warszawa 2011, s. 273-275. Na temat alternatywnych translacji zob.: M. Świerkosz, Ciała podatne na zranienie. Judith Butler, samozniszczenie i radykalne akty oporu, „Etyka”, nr 57 (2018), s. 69-86. É. Féron, op. cit., s. 121. Por.: L. Abrams, Oral History Theory, London-New York 2010, s. 19. Por.: A. Jones, op. cit., s. 461. VHA, usc Shoah Foundation, sygn. 47265, Relacja Andrzeja Kotarskiego, 8 vi 1998 r. (sporządziła Z. Zaks). Transkrypcji wywiadu autorka artykułu dokonała samodzielnie. 
W drugiej rozmowie, przeprowadzonej w roku $2007^{22}$ i dostępnej wyłącznie w formie zapisu audio, wykorzystany zostaje omówiony już schemat myślenia o ofierze-mężczyźnie - pierwotnie mający służyć skompromitowaniu pipli i, paradoksalnie, potwierdzający ich status jednej z najsłabiej rozpoznanych i przebadanych grup ofiar nadużyć seksualnych w obozach koncentracyjnych ${ }^{23}$. To w tej relacji rozwijana jest opowieść o permanentnym poczuciu (homo)seksualnego zagrożenia jako jednym z najboleśniejszych wspomnień okresu uwięzienia. Gotowość Kotarskiego do powiedzenia czegoś więcej w drugim ze świadectw może wynikać z przemian, jakim w przeciągu blisko dekady podlegała świadomość społeczna; może też być wyrazem osobistych przewartościowań i próbą pełniejszego wyartykułowania pewnych wrażeń, emocji i stanów. Powodzenie zamiaru świadka nie zależy jednak wyłącznie od niego ${ }^{24}$, a bariera „nieczytalności” (unreadability) skutecznie oddziela odbiorcę od treści, które pozostają niejawne.

\section{„Gross-Rosen wspominam bardzo przykro”. Granice wypowiadalności}

Warszawiak Andrzej Kotarski (ur. w 1926 r.) wstąpił do Szarych Szeregów na przełomie 1941 i 1942 r. W maju 1942 r. został aresztowany, a po dwunastomiesięcznym osadzeniu na Pawiaku przetransportowany do obozu na Majdanku. Od kwietnia 1944 do lutego 1945 r. przebywał w Gross-Rosen, następnie ewakuowano go do obozu w Leitmeritz, gdzie doczekał wyzwolenia. Przerwaną edukację (nauka w liceum francuskim, następnie, podczas okupacji, w gimnazjum ogólnym i gimnazjum rolniczym) kontynuował po wojnie za granicą (w Norymberdze i Monachium). Do Polski wrócił w 1947 r.; ukończył studia chemiczne, uzyskał stopnień doktora i objął stanowisko kierownicze w zakładzie analitycznym Instytutu Przemysłu Organicznego.

Pierwszą z dwóch analizowanych relacji autobiograficznych Andrzej Kotarski złożył 8 czerwca 1998 r. na potrzeby usc Shoah Foundation - The Institute for Visual History and Education. Fakt, że rozmawiała z nim kobieta (Zofia Zaks)

Archiwum Historii Mówionej Ośrodka KARTA i Domu Spotkań z Historią, sygn. AHM_0130, Relacja Andrzeja Kotarskiego, 23 i 27 I 2007 r. (sporządził J. Pałka). Udostępnioną na stronie internetowej transkrypcję uzupełniłam o niewerbalne reakcje świadka (np. śmiech, zawahanie, cisza), odnotowane w nawiasach kwadratowych. Por.: R. Sommer, op. cit., s. 96. Na ambiwalentność statusu pipli zwraca uwagę również Wolfgang Sofsky, stwierdzając, że byli oni „szczególnie uprzywilejowani, ale także szczególnie zagrożeni. Ujawniając skłonności swojego partnera, narażali nie tylko jego, ale i samych siebie. Za materialne korzyści płacili całkowitą bezsilnością"; W. Sofsky, Ustrój terroru: obóz koncentracyjny, Warszawa 2016, s. 184.

24 Zdaniem Lynn Abrams, na samym świadku nigdy nie spoczywa wyłączna odpowiedzialność za ostateczny kształt relacji, chociażby ze względu na wspomniany już, dialogiczny charakter historii mówionej. Por.: L. Abrams, op. cit., s. 27. 
wydaje się nie bez znaczenia dla treści interesującego mnie fragmentu i całego, blisko dwuipółgodzinnego nagrania, zwłaszcza w porównaniu z relacją późniejszą. Jeszcze zanim pojawia się temat obozowej homoseksualności (dopiero po upływie około dwóch godzin rozmowy) Kotarski zostaje przez Zaks zagadnięty o stosunki damsko-męskie w obozie:

Zofia Zaks: Jeszcze chciałam pana o jedną rzecz zapytać: czy wtedy na Majdanku pan miał jakiś kontakt kiedykolwiek z jaką́s paniq, kobieta, dziewczyna?? To znaczy $c z y$ kontakty z kobietami tam byty możliwe, czy nie?

Andrzej Kotarski: Były możliwe, to wiem, ja sam nie miałem, mnie to jeszcze wtedy nie interesowało [uśmiech, lekkie rozbawienie].

Z.Z.: Nie, nie, to znaczy ja myślę nie o emocjonalnych sprawach, tylko, bo ja wiem, jakiś kawałek chleba...

A.K.: Były, były możliwe, bo był ten blok, znaczy pole kobiece, no niby tylko dla kobiet, ale one też wychodziły, prawda, zresztą to potem...

Z.Z.: Czy ktoś miał na przykład siostrę czy matkę z pana wspótwięźniów tam, po tamtej stronie?

A.K.: Akurat z tych co ze mną...

Z.Z.: Tak?

A.K.: To nie pamiętam, ale wiem, że takie sytuacje były ${ }^{25}$.

Przytoczoną wymianę zdań charakteryzuje rodzaj nieporadności czy niezręczności: odpowiadając na pytanie, Kotarski zasłania się ówczesną niedojrzałością psychoseksualną i choć w jego wypowiedzi pobrzmiewa nuta rozbawienia, wręcz pobłażliwości względem młodszej wersji siebie, Zaks czuje się w obowiązku wyjaśnić swoje intencje, jakby chciała zapobiec ewentualnym nieporozumieniom. Na tym etapie można odnieść wrażenie, że pod pojęciem „emocjonalnych spraw”, od których przeprowadzająca wywiad niejako się odcina, kryje się również sfera dyskursywnego tabu: kacetowej cielesności i seksualności. Samą Zaks zdają się interesować raczej motywy i wątki dalece bardziej oswojone, kanoniczne - głód, samopomoc więźniarska, relacje rodzinne za drutami ${ }^{26}$. W ten dobrze już rozpoznany schemat doskonale wpisują się kolejne wspomnienia Kotarskiego: o transporcie do Gross-Rosen (i udaremnionym zamiarze ucieczki), epizodzie obrzucania nowo przybyłych Polaków kamieniami przez członków Hitlerjugend oraz utraty przytomności podczas apelu, kiedy to inny więzień przemocą starał się zmotywować go do wstania.

Relacja A. Kotarskiego z 1998 r.

Kolejny fragment rozmowy pokazuje, że próby uzyskania przez badaczkę informacji o obozowych relacjach homoseksualnych wśród kobiet nie przyniosły efektów - z pewnością miało to wpływ na jej powściągliwość w rozmowie z Kotarskim. 
Następującą bezpośrednio potem wymianę zdań o obozowych relacjach homoseksualnych przytaczam w całości:

A.K.: Gross-Rosen to było, że tak powiem, całkiem inny obóz niż...

Z.Z.: Niż Majdanek?

A.K.: Majdanek. Majdanek to był brud, smród, błoto, prawda, bezład. Gross-Rosen - pięknie utrzymany kawałek terenu, z ładnie pomalowa[nymi]..., nie wiem, czy one były pomalowane, ale ładnie utrzymane bloki, ze ścieżkami, z kwiatami w takich donicach w środku, porządek tam panował i tego. [odchrząknięcie] Dla mnie Gross-Rosen był znacznie gorszy od Majdanka. [ściszenie głosu] Znacznie był gorszy od Majdanka, chociaż znalazłem tam pracę, dobrą. Ale tam się włączyła rzecz, która na Majdanku nie istniała. Mianowicie: homoseksualizm [podniesienie palca wskazującego, spojrzenie bezpośrednio na przeprowadzająca wywiad].

Z.Z.: Proszę o tym opowiedzieć, bo ja wielu osobom zadawałam to pytanie i jakoś... U kobiet to inaczej wyglądało, panie mi nie potrafity nic o tym powiedzieć...

A.K.: Proszę pani. Przede wszystkim w Gross-Rosen siedziało więcej Niemców, kryminalistów lub tych z różowymi winklami [zarysowanie kształtu winkla na piersi palcem wskazującym].

Z.Z.: Czyli homo... Podejrzanych osób o homoseksualizm.

A.K.: Niekoniecznie o ho... o jakiekolwiek zboczenie seksualne.

Z.Z.: Dewiacje, tak.

A.K.: Tak [odkaszlnięcie]. I oni starali... Jeżeli dostali się na funkcję, prawda, że znaczy... Po prostu [jeśli] byli zdolni do jakiejśkolwiek czynności obozowej, no to starali się kontynuować. I wybierali sobie z innych więźniów zawsze jakichś młodszych [patrzenie na przeprowadzająca wywiad]...

Z.Z.: [uzupełniająco, ze zrozumieniem] Chłopców.

A.K.: Chłopców, prawda. I to oczywiście się rozprzestrzeniło też i na innych więźniów, na nieszczęście. Też Polaków, też politycznych.

Z.Z.: Czyli jakoś pod wpływem tego zaczęli próbować...?

A.K.: [potakiwanie głowa] Pod wpływem... Tamci, niektórzy, oczywiście nie wszyscy, niektórzy nie tego. I, wie pani, i ja, chcąc nie chcąc, niezależnie od tego, że nic z tym nie miałem wspólnego, byłem traktowany jak prostytutka [cisza].

Z.Z.: Hm.

A.K.: Bo młody, jako tako wyglądający - no, to pipel musi być.

Z.Z.: Mhm.

A.K.: I dla mnie to było bardzo, bardzo nieprzyjemne i ja Gross-Rosen z tego punktu widzenia wspominam bardzo przykro [z powaga].

Z.Z.: Czy tam była jakaś organizacja również, to znaczy czuł pan rękę organizacji tam, w Gross-Rosen? 
A.K.: Nie. Nie, nie czułem...

Z.Z.: Rozumiem.

A.K.: ... i nie mogę powiedzieć, czy było...

Z.Z.: Rozumiem.

A.K.: ... czy nie było, chociaż...

Z.Z.: A czy ktoś z innej...

A.K.: ... byli ludzie, którzy byli w organizacji na Majdanku.

Z.Z.: Ja rozumiem.

A.K.: A, i niektórzy z nich się dostali przecież do tych, do karnych kompanii, czyli być może coś wykryto.

Z.Z.: $M h m$.

A.K.: No, więc tak pośrednio mogli.

Z.Z.: Czy ktoś pana tam próbował bronić, pana i innych młodych chłopców?

A.K.: Nie. Nie, tam tego nie było [pauza]. Tam trzeba było się samemu bronić.

Z.Z.: Rozumiem.

[cisza, westchnięcie obojga]

A.K.: I... I proszę pani, i tam dostałem się do komanda elektryków²7.

Od początku cytowanej wypowiedzi, znaczenie dla świadka tego bardzo osobistego doświadczenia wyraża się na różne sposoby (tembr głosu, gestykulacja). Zaks z kolei nie tylko zdradza zainteresowanie tematem, którego jak dotąd nie udało jej się zgłębić, lecz także wykazuje się językową wrażliwością (np. nie mówi o „homoseksualistach”, tylko o „osobach podejrzanych o homoseksualizm”). Odpowiedzialność za występowanie w obozie Gross-Rosen tego zjawiska Kotarski przypisuje konkretnej grupie narodowościowej (niemieccy kryminaliści i niemieccy więźniowie z różowym trójkątem); posługuje się pejoratywną metaforyką chorobową („rozprzestrzenianie się”), zaś przyznając, że również polscy więźniowie polityczni angażowali się „na nieszczęście” w tego rodzaju relacje, sięga po retorykę wpływu, podchwyconą zresztą przez prowadzącą wywiad. Wyraźnie podkreślając brak swojej sprawczości w tamtym okresie, Kotarski stwierdza, że „był traktowany jak prostytutka”, a następnie używa określenia "pipel” (o którego znaczenie Zaks, zapewne je znając, nie dopytuje) ${ }^{28}$. Choć oba te sformułowania (pipel i prostytutka) wydają się dość jednoznaczne, na tym etapie niepodobna stwierdzić, czy Kotarskiemu wciąż trudno pogodzić się z utrzymującym się w czasie pobytu w Gross-Rosen poczuciem „podatności per se” (vulnerability), otrzymywaniem określonych propozycji lub kojarzeniem go - wbrew jego

28 W późniejszym fragmencie Kotarski stosuje - tylko raz, być może więc omyłkowo - żeńską formę tego określenia („pipla” zamiast „pipel”). 
woli - z powszechnie potępianymi zachowaniami i postawami, czy może jest on ofiarą homoseksualnych nadużyć, o których nie mówi wprost.

Na problemy z wyartykułowaniem pewnych doświadczeń wskazuje także wysoki stopień eufemizacji języka („bardzo, bardzo nieprzyjemny” sposób traktowania go i spowodowane tym „bardzo przykre wspominanie” Gross-Rosen). Pytanie Zaks o istnienie organizacji nie wydaje się dotyczyć wyłącznie obozowego ruchu oporu rozumianego w kategoriach politycznych; to raczej pytanie o kondycję potencjalnej ofiary. Zwłaszcza, że po gorzkiej konstatacji Kotarskiego („Tam trzeba było się samemu bronić”) zapada znacząca cisza; z ust obojga rozmówców wydobywa się po chwili westchnienie symbolizujące tyleż bezradność, co niemożliwość kontynuowania tematu. Najlepszym sposobem, by się od niego odciąć, okazuje się powrót z marginesów obozowego dyskursu do jego ścisłego centrum: Kotarski sam inicjuje opowieść o pracy w komandzie elektryków, po której zakończeniu przechodzi do omawiania zjawiska ucieczek z obozu.

\section{„Walka o cnotę” i „panna na wydaniu”. Performowanie dystansu i kontroli Drugą, ponadczterogodzinną rozmowę z Kotarskim, stanowiącą część projek- tu „Relacje Biograficzne Archiwum Historii Mówionej”, przeprowadził 23 i 27 stycznia 2007 r. Jarosław Pałka. Temat obozowej homoseksualności oraz prze- mocy homoseksualnej Kotarski podejmuje w niej stosunkowo wcześnie, bo już w czterdziestej minucie relacji, zaraz po tym, gdy w narracji dochodzi do zmiany miejsca akcji na drugi z obozów - Gross-Rosen. Świadczyć to może o roli, jaką w jego pamięci odgrywa utrzymujące się wówczas poczucie (homo)seksualnego zagrożenia ze strony innych więźniów i niebezpieczeństwo stania się piplem (by- cia traktowanym jak pipel? uchodzenia za pipla?):}

Trafiłem do Gross-Rosen. Majdanek i Gross-Rosen to były dwa różne światy. Majdanek to było błoto, drewniane baraki, pełno drutów kolczastych, ale nienaelektryzowanych, a jednocześnie organizacja wśród więźniów, paczki dochodziły. Tak że można powiedzieć ogólnie, że jeżeli ktoś przetrzymał pierwsze dwa, trzy miesiące, to miał szansę przeżyć. Dostał się do jakiegoś lepszego komanda i tak dalej. Natomiast Gross-Rosen to były murowane bloki, pięknie urządzone ścieżki. Jak to się nazywa takie na kwiaty...? Takie, wie pan. Może patery czy jak to się nazywa? Trawniki.... [pauza]. I co dla mnie było szczególnie bolesne: homoseksualizm. A, jeszcze. Majdanek to sami polityczni Polacy, Gross-Rosen - owszem, większość politycznych Polaków, ale władzę wewnątrz mieli kryminaliści niemieccy i oni narzucali różne...29 
Podobnie jak w pierwszym wywiadzie, Kotarski pokrótce charakteryzuje nową, obozową przestrzeń, która poziomem estetyki znacznie odbiegała od tej znanej mu z Majdanka. Następnie, w żaden sposób nie sygnalizując zmiany przedmiotu opisu, inicjuje kolejny, „szczególnie dla niego bolesny” temat: homoseksualnych relacji w obozie. Przy tej okazji skrótowo, lecz w sposób niezwykle charakterystyczny (znów: podobnie jak w rozmowie z Zaks), kreśli linię narodowo-moralnych podziałów ${ }^{30}$. W tym sensie poprzedni obóz jawi się Kotarskiemu jako bardziej bezpieczny (przynajmniej ze strony współosadzonych), bo zdominowany przez polskich więźniów politycznych, dla większości których normę stanowiła heteroseksualność. W Gross-Rosen ważniejsza niż liczebna przewaga (tutaj także mieli ją Polacy) staje się realna strefa wpływów: zagrożenie uosabiają niemieccy więźniowie kryminalni, wymuszający określone - z punktu widzenia Kotarskiego nieakceptowalne i niebezpieczne - zachowania.

Kotarski nie doprecyzowuje, co takiego narzucali niemieccy więźniowie kryminalni, a po wypowiedzeniu niedokończonego zdania, na moment milknie. Już po chwili dobrowolnie decyduje się jednak nieco rozwinąć podjęty wątek:

Tak że o ile Majdanek, poza pierwszym miesiącem, chyba, albo nawet więcej, może dwoma miesiącami, które były bardzo fatalne, to zupełnie dobrze przeżyłem, to Gross-Rosen był cały czas dla mnie... [cisza] Czułem się, wie pan [cisza, westchnięcie], jak by to powiedzieć... [cisza] jak... panna na wydaniu [parsknięcie śmiechem, żartobliwie], czy jak to tak określić, w każdym razie ciągle musiałem walczyć o moją cnotę [cisza]. Różnie to się objawiało, szczególnie na początku, chociaż nie - do końca to było ${ }^{31}$.

Kotarski ma świadomość sytuacji komunikacyjnej, w jakiej się znajduje oraz jej konsekwencji. Wie, że nad słowem mówionym - nawet, dodajmy za Piotrem Filipkowskim, zarejestrowanym - „zapanować nie sposób”32. Nie da się go „na-

30 Kryterium narodowościowe w dużym stopniu kształtowało linie obozowych hierarchii i podziałów. Andrzej Werner zwraca uwagę, że polscy więźniowie z największą rezerwą traktowali osadzonych w kacetach Niemców oraz że „synonimem zła stało się [w polskiej literaturze obozowej typu martyrologicznego - przyp. aut.] połączenie: niemiecki kryminalista [...]". Choć badacz nie wyklucza zakorzenienia tego rodzaju przedstawień w rzeczywistości, jednocześnie zwraca uwagę, iż „stały się czymś więcej niż stwierdzeniem stanu faktycznego, a mianowicie uniwersalną zasadą wyjaśniającą istnienie zła"; A. Werner, Zwyczajna apokalipsa. Tadeusz Borowski i jego wizja świata obozów, Warszawa 1981, s. 32.

31 Relacja A. Kotarskiego z $2007 \mathrm{r}$.

32 P. Filipkowski, Historia mówiona jako historia ratownicza: doświadczenie, opowieść, egzystencja, „Teksty Drugie”, nr 5 (2014), s. 41. 
tychmiast (albo później) skreślić, poprawić, rozwinąć” ${ }^{33}$. Znaczący wydaje mi się w tym kontekście zmultiplikowany gest autofeminizacji: ewidentnie poszukując języka, który pozwoliłby jak najtrafniej - ale jednak nie wprost - określić własne położenie w danym momencie życia, Kotarski najpierw używa określenia „panna na wydaniu”, a potem wykorzystuje metaforę „walki o cnotę”. Jednocześnie ton głosu zdradza, że stara się on brzmieć żartobliwie, jakby podświadomie podważał albo przynajmniej próbował osłabić traumatyczny wymiar opisywanych wydarzeń. Wewnętrzna niespójność przekazu, z oczywistych względów trudniej uchwytna w zapisie audio i transkrypcji, daje o sobie znać za każdym razem, gdy Kotarski milknie lub parska nieco nerwowym śmiechem. Reakcje te stają się komunikatem samym w sobie ${ }^{34}$.

Wątek homoseksualnych relacji obozowych powraca w późniejszej części wywiadu. Odpowiedziawszy na pytania dotyczące przeprowadzanych na placu apelowym egzekucji, Kotarski mówi:

Wiem, że był taki... ten... Feldälteste? Nie wiem, jak on się nazywał. W każdym razie taki Niemiec, który zarządzał polem. I on sobie dobrał [dłuższa cisza] pipla. Pipla, to był młody chłopak, który był kochankiem starszego. Takiego pipla Żyda, młodziutkiego. Tamten chłopak miał może dziesięć lat, może dwanaście, jedenaście, coś takiego. I z nim odbierał ranne i popołudniowe, i południowe, i wieczorne apele. I to nie ten Niemiec się znęcał nad więźniami, tylko ten pipel się znęcał. Na ogół nad tymi, którzy upadli, bo już nie mieli siły stać, prawda. No takie były... [dłuższa cisza] No i tutaj to tak byłem... ja byłem chyba do trzech miesięcy na tym polu, może niecałe trzy miesiące. Jak potem... Nie wiem, jakim cudem się znalazłem w tym komandzie, trzyosobowym zresztą, które obsługiwało lazaret niemiecki. No i tam to już można było żyć ${ }^{35}$.

Nim postawię hipotezę dotyczącą tożsamości „pipla Żyda, młodziutkiego”, o którym mowa powyżej, pozwolę sobie przypomnieć kwestię oczywistą: podejmowana w ramach oral history refleksja nad rolą (właściwych) pytań obejmuje swym zasięgiem nie tylko kwestie czysto językowe czy proces pozyskiwania informacji; pytania - zadane i niezadane - wpływają również na dynamikę mówienia, wypowiedzenia, wysłowienia pamięci i towarzyszących emocji, nie jest przerwą w komunikacji”. Badacz dodaje także, że „warto wsłuchiwać się w nią jeszcze uważniej, nie poprzestawać na lekturze transkrypcji z wykropkowaniem. Załamanie głosu rozmówcy, cisza, towarzyszące jej wzruszenie [...] odsłania rozmówcę, czyni go na chwilę bezbronnym wobec nas"; P. Filipkowski, Historia mówiona i wojna. Doświadczenie obozu..., s. 33 . 
i przebieg konwersacji, towarzyszące jej emocje i atmosferę ${ }^{36}$. Osoba przeprowadzająca wywiad „musi być gotowa pytać o rzeczy bolesne i zawstydzające, jednocześnie respektując prawo do nieudzielenia odpowiedzi"37. Do sytuacji komunikacyjnej, w której szansa na zadanie narzucającego się - przynajmniej z dzisiejszej perspektywy - pytania pozostaje niewykorzystana, dochodzi w późniejszej części wywiadu, podczas opowieści o rewirze na Majdanku, w którym Kotarski pracował jako sanitariusz. Jej zakończenie brzmi następująco:

A.K.: To tyle, co na temat tych służbowych, tych. O tym piplu Żydzie to panu opowiadałem. Też znana to historyczna postać, opisywana.

J.P.: To teraz proszę, jakby pan mógł mi powiedzieć o tej wywózce, o tym transporcie.

A.K.: Do Gross-Rosen, tak?

J.P.: Do Gross-Rosen, tak $^{38}$.

Powracającym w wypowiedzi Kotarskiego „piplem Żydem”, „znaną i opisywaną historyczną postacią", może być nastoletni chłopiec żydowskiego pochodzenia, nazywany Bubim, który pojawia się w co najmniej kilkunastu opublikowanych drukiem relacjach byłych polskich więźniów politycznych KL Lublin ${ }^{39}$. Figuruje on także w wykazie tamtejszych więźniów funkcyjnych, stworzonym przez twórców nieoficjalnej strony internetowej poświęconej historii obozu. Według opublikowanych tam informacji, „Bubi” pełnił funkcję Lagerjüngste (młodszego obozu), rzekomo zawdzięczaną zabójstwu własnych rodziców. Najprawdopodobniej zginął wraz z innymi żydowskimi więźniami, zamordowany podczas akcji „Erntefest” (nazywanej też operacją „Dożynki”) w listopadzie 1943 r.40

Fakt, że Jarosław Pałka nie prosi Kotarskiego o doprecyzowanie, kogo ma na myśli i nie odnosi się do tej - pojawiającej się niejako mimochodem - wzmianki,

36 Por.: M. Jarząbek, It is good to ask good questions: posing questions in oral history interview as a theoretical problem, „Wrocławski Rocznik Historii Mówionej”, R. 6 (2016), s. 22.

37 D.A. Ritchie, Doing Oral History. A practical guide, Oxford 2015, s. 19.

38 Relacja A. Kotarskiego z $2007 \mathrm{r}$.

39 Co ciekawe, na wzmianki o innym „Bubim” natrafić można także w wydanych drukiem wspomnieniach byłych więźniów kL Dachau. O „młodym, kilkunastoletnim Francuzie z Belgii” kard. Adam Kozłowiecki pisze: „Twarzyczka przystojna, ale dusza...! Trudno zrozumieć, jak w tym wieku mógł dojść do tak strasznego zepsucia. Jest to po prostu prostytutka obozowa i wcale się tego nie wstydzi...”. Według Bronisława Najnigiera "adoratorom nie szczędził [on] swych wdzięków za odpowiednim wynagrodzeniem, przyjmując ich w sypialni”; zob.: A. Kozłowiecki, Ucisk i strapienie, Kraków 2008, s. 478; B. Najnigier, Powrót z daleka, Warszawa 1973, s. 223. Zob.: http://www.majdanek.com.pl/obozy/majdanek/funkcyjni\%2o(m).html (dostęp: 20 vi 2021 r.). 
uniemożliwia uzyskanie odpowiedzi na pytanie, czy Kotarski wspomina pipla okrytego bodaj największą niesławą w polskich narracjach obozowych, o prawdziwej tożsamości którego niewiele wiadomo, czy inną osobę, pełniącą w obozie na Majdanku podobną funkcję.

Najistotniejszy dla mojej refleksji wątek nie zostaje jednak porzucony całkowicie. Po odpowiedzi na pytanie dotyczące okresu kwarantanny po przybyciu do obozu, w końcowej części wywiadu Pałka ostrożnie zachęca Kotarskiego, by ten powrócił do tematu relacji homoseksualnych w obozach:

J.P.: Mówił pan jeszcze o tym zjawisku homoseksualizmu.

A.K.: Homoseksualizmu... No był, bo wszyscy Niemcy, prawda, i nieliczni Polacy byli... no to częściowo to był wymuszony homoseksualizm. Wie pan. Jeżeli tam się komuś dobrze działo, to tak jak w wojsku, no nie było ujścia, prawda, więc to było czasami wymuszane. Ja miałem właśnie taki nieprzyjemny przypadek. Posłał nas kapo do reperacji, do układania przewodów. Wie pan, to był barak drewniany. Taki barak - między sufitem a dachem była pewna przestrzeń. I tam na tym suficie u góry szły wszystkie przewody elektryczne, i tam musieliśmy wpełznąć, bo to nawet stanąć nie można było, może uklęknąć można było, bo ten dach był taki tego. Trzeba było tam pełzać i reperować. No i zaczął się do mnie dobierać [cisza, odgłosy kobiecego nucenia $w$ tle $e^{41}$. Taki Polak zresztą, Polak. To było typowe, on myślał, że ja jestem pipel. Dlaczego tak myślał...? Może tylko okazji szukał.

J.P.: Pan mu coś tam powiedziat, tak?

A.K.: Nie no, tylko żeby wziął ręce od siebie i precz. Czy odepchnąłem go, pewnie, czy coś takiego. No i dał mi potem spokój. Groził mi [hałasy w tle], ale się nie przejąłem i tym sposobem...

J.P.: Ale ci funkcyjni niemieccy, tak [kobiece podśpiewywanie w tle], to często... tam to byto powszechne.

A.K.: To było powszechne, to było powszechne [w tle coraz głośniejsze kobiece podśpiewywanie $]^{42}$.

Uwagę zwracają tu trzy rzeczy: po pierwsze, zjawisko homoseksualności obozowej Kotarski próbuje zracjonalizować, odwołując się do logiki rzekomo rządzącej każdą zamkniętą homospołecznością ${ }^{43}$. Po drugie, choć nie podaje personaliów

41 Podśpiewująca osoba to żona Kotarskiego, przez cały czas obecna w mieszkaniu i najwyraźniej przygotowująca posiłek, do którego zjedzenia będzie zachęcać w końcowej części nagrania.

42 Relacja A. Kotarskiego z $2007 \mathrm{r}$.

43 Na temat tej kategorii zob.: M. Skucha, Homospołeczność, [w:] Encyklopedia gender. Płeć w kulturze, red. K. Czeczot [et al.], Warszawa 2014, s. 203-206. 
niedoszłego napastnika, nie zataja ani nie zafałszowuje jego narodowości; szczerze - jakby z nutą rozczarowania pobrzmiewającą w głosie - przyznaje, że był to Polak. Po trzecie, od pewnego momentu rozmowie towarzyszą wyraźne zakłócenia - w tle słychać hałasy, kobiece podśpiewywanie. Odgłosy nasilają się w chwili, gdy Kotarski mówi o groźbach pod swoim adresem, będących efektem powstrzymanej napaści seksualnej, stają się głośne na tyle, że właściwie utrudniają przeprowadzającemu wywiad, skupienie się na rozmowie i zadanie kolejnego pytania o brutalne zachowania funkcyjnych.

Z całą pewnością takie warunki składania relacji - zwłaszcza fragmentów dotyczących intymnych, wstydliwych, być może traumatycznych przeżyć - nie były komfortowe, choć niewykluczone, że Kotarskiemu nie przeszkadzała obecność żony. Przypuszczalnie znała ona tę część jego obozowej historii i raczej nie zakłócała jej naumyślnie. Warto dodać, że nim proces składania świadectwa dobiegł końca, ze strony Pałki padło pytanie o to, co - w szeroko pojętym doświadczeniu kacetu - było dla Kotarskiego najgorsze:

A.K.: Oczywiście, to tylko subiektywnie, można i obiektywnie, ale... [cisza] Obiektywnie to była... najgorsza była ciężka praca z małą ilością jedzenia, bo to było wstępem do wszystkiego innego. Bo co innego, jak pobiją zdrowego, odżywionego mężczyznę, a co innego jak wychudzonego, wygłodniałego, zmęczonego, prawda? Więc to było takie pierwsze. Dalej, no to te wszelkiego rodzaju szykany, bicie, tego, które jednakże pod koniec to coraz rzadziej się zdarzało. Coraz rzadziej się zdarzało. Niemcy już wiedzieli, co się dzieje. A mnie osobiście, mnie osobiście, ale to w Gross-Rosen, prawda, ten: traktowano mnie jako pipla, prawda. Nie bardzo miałem... [pauza] Bo to nawet jak się do mnie nie zalecano, że tak powiem, to ponieważ byłem młody - mały i młody - no to uważano, że muszę być czyimś piplem, prawda. A na Majdanku tego w ogóle nie było, nie pomyślano - ja w ogóle nie wiedziałem, o co chodzi na początku.

J.P.: Mhm.

A.K.: Jak byłem... Jak zostałem wzięty do niewoli, to teoretycznie byłem uświadomiony, ale nie praktycznie ${ }^{44}$.

W finale ostatniej z cytowanych wypowiedzi ponownie pobrzmiewa nuta rozbawienia. Zaśmiawszy się, mężczyzna zmienia wątek; nieuchronnie zbliżający się koniec procesu świadczenia sprawia, że relacja staje się coraz bardziej chaotyczna. Tym samym równoległy do kwestii męskiej homoseksualności i homoseksualnej przemocy temat inicjacji seksualnej, a przynajmniej pierwszego zetknięcia 
z ludzką seksualnością i fizycznością w dalece odbiegających od normy warunkach obozowej rzeczywistości, z całą pewnością niewyczerpany, zostaje porzucony. Jasne staje się z kolei, że prócz „zalecania się” (kolejne określenie autofeminizujące) uciążliwe było dla Kotarskiego samo postrzeganie go jako pipla.

Co ważne, śmiechu mężczyzny nie da się sprowadzić do „nieświadomej, spontanicznej reakcji" 45 wywołanej przez określony bodziec. Odgrywa on raczej rolę kolejnego - po sfeminizowanym języku - narzędzia wykorzystywanego do performowania po pierwsze dystansu względem traumatycznych przeżyć, po wtóre kontroli: nad narracją o nich, ale także nad zagrożonym poczuciem męskości. Odróżnienie śmiechu od humoru jako takiego jest tym istotniejsze, że - wedle wykładni Stéphanie Panichelli-Batalli ${ }^{46}$ - to właśnie ten pierwszy skłania do przemyślenia znaczeń przypisywanych przez jednostkę swojej przeszłości i pozwala wysondować, jakie emocje towarzyszą opowiadaniu o konkretnych wydarzeniach ${ }^{47}$. Postawa Kotarskiego sugeruje, że jest on świadomy przełamywania silnego, społeczno-kulturowego tabu: opowiadając o podatności na (homoseksualne) zranienie, obsadzając samego siebie w roli potencjalnej ofiary, jednocześnie próbuje jak najszybciej przekroczyć tę - raczej nieobecną w obozowo-pamięciowym dyskursie, a przez to nierozpoznaną i nieoswojoną - kondycję.

\section{Przełamywanie tabu a problem „nieczytalności” (unreadability)}

Wybrane fragmenty relacji Kotarskiego, odwołujące się do męskich homoseksualnych relacji obozowych, wpisują się w zaproponowaną przez Jessicę Lang koncepcję „nieczytalności” (unreadability), synonimicznie określanej mianem „tekstualnej ciszy" (textual silence). Choć mamy tu do czynienia z przekazem ustnym, nie pisanym, charakter źródła bynajmniej nie wyklucza wystąpienia w nim „niedostępności, pustki, nieczytalności”48. Wprost przeciwnie: ów specyficzny rodzaj ciszy, którą da się „wyczytać” (usłyszeć bądź w jakikolwiek inny sposób wychwycić), a która przypomina pustą przestrzeń wypełniającą całą stronę lub strony maszynopisu i stanowi wyzwanie dla przyjętych norm czytelniczych (lub odbiorczych), daje o sobie znać kilkukrotnie. Jej przejawy to wszystkie momenty „braku iluminacji” (non-ilumination) ${ }^{49}$ w procesie obcowania ze świadectwem: to

Zob.: https://oralhistoryreview.org/current-events/panichelli-laughter/ (dostęp: 20 vi $2021 \mathrm{r}$.).

Zob.: S. Panichelli-Batalla, Laughter in Oral Histories of Displacement: „One Goes on a Mission to Solve Their Problems”, „The Oral History Review”, t. 47 (1/2020), s. 73-92. Zob. także: N.R. Norrick, Humour in Oral History Interviews, „Oral History”, t. 34 (2/2006), s. 85-94.

Zob.: https://oralhistoryreview.org/current-events/panichelli-laughter/ (dostęp: 20 vi 2021 r.).

48 J. Lang, op. cit., s. 3.

9 Por.: ibidem. 
te partie wypowiedzi, do których - przez fakt ich niewypowiedzenia - nie sposób dotrzeć, które stawiają opór próbom interpretacji i zdekodowania ${ }^{50}$. To nie tylko pauzy, dosłownie rozumiane milczenie, westchnięcia czy zawahania. To ewidentne niedopowiedzenia, brak całych zdań czy pojedynczych słów, który nie pozwala na jednoznaczne diagnozy i rozmywa obraz opisywanej rzeczywistości. To również eufemistyczny język, skrywający określone treści i, paradoksalnie, wyraźnie sygnalizujący ich istnienie. Strategia autofeminizacji może być wyrazem nieświadomego zinternalizowania obozowych wzorców myślenia, może też jednak, podobnie, jak śmiech, służyć performowaniu niedostępnej przed laty sprawczości i siły (skojarzenia z kobiecością pochodzą od samego Kotarskiego, nikt nie projektuje ich na niego z zewnątrz; można je więc obśmiać, zneutralizować ich negatywny wydźwięk, a w konsekwencji: zdezaktualizować). Niewypowiadalne, „nieczytalne” wymiary obu relacji bynajmniej nie osłabiają ich wymowy - obie składane były przecież w warunkach całkowitej niemal tabuizacji tematu męskiej przemocy seksualnej ${ }^{51}$.

Mimo że analizowane tu fragmenty relacji Kotarskiego ukazują niepełny obraz interesującego mnie zagadnienia, jako źródło są zupełnie wyjątkowe: przełamują tabu otaczające obozową (homo)seksualność, (homo)seksualną przemoc oraz - zmitologizowaną raczej niż rzetelnie przebadaną - figurę pipla. Opowieści Kotarskiego, ze wszystkimi charakterystycznymi dla nich lukami, przemilczeniami i niedopowiedzeniami, oferują coś więcej niż tylko opis abstrakcyjnego fenomenu, w dodatku z pozycji bezpiecznego oddalenia. Na pierwszy plan każdorazowo wysuwa się tu osobisty, traumatyczny wymiar doświadczenia, którego całkowita artykulacja okazuje się, pomimo podejmowanych prób, zadaniem niemożliwym.

50 Por.: ibidem.

51 Zob.: A. Jones, op. cit., s. 463. 


\section{Bibliografia}

Abrams L., Oral History Theory, London-New York 2010.

Author Interview: Stéphanie Panichelli-Batalla on Laughter in Oral History Interviews, https://oralhistoryreview.org/current-events/panichelli-laughter/ (dostęp: 20 vi 2021 r.).

Baldwin A., 'And What Happened Next?': Emotions and Sexual Violence in Holocaust Interviews, „Oral History Australia Journal", nr 41 (2019), s. 32-42.

Curry T.J., Thinking through the silence: theorizing the rape of Jewish males during the Holocaust through survivor testimonies, „Holocaust Studies”, nr 1 (2020), s. 1-27.

Czarnacka A., Posłowie od tłumaczki, [w:] J. Butler, Ramy wojny. Butler Judith, Kiedy życie jest godne opłakiwania?, Warszawa 2011, s. 273-275.

Féron É., Wartime Sexual Violence Against Men. Masculinities and Power in Conflict Zones, Lanham 2018.

Filipkowski P., Historia mówiona i wojna. Doświadczenie obozu koncentracyjnego w perspektywie narracji biograficznych, Wrocław 2010.

Filipkowski P., Historia mówiona jako historia ratownicza: doświadczenie, opowieść, egzystencja, „Teksty Drugie”, nr 5 (2014), s. 40-6o.

Głowacka D., Sexual Violence against Men and Boys during the Holocaust: A Genealogy of (Not-SoSilent) Silence, „German History”, t. 39 (1/2020), s. 78-99.

Grzesiuk S., Pięć lat kacetu, Warszawa 1972.

Heineman E., Sexuality and Nazism: The Doubly Unspeakable?, ,Journal of the History of Sexuality" t. 11 (1-2/2002), s. 22-66.

Jarząbek M., It is good to ask good questions: posing questions in oral history interview as a theoretical problem, „Wrocławski Rocznik Historii Mówionej”, R. 6 (2016), s. 21-31.

Jones A., Straight as a Rule: Heteronormativity, Gendercide, and the Noncombatant Male, „Men and Masculinities", t. 8 (4/2006), s. 451-469.

Kozłowiecki A., Ucisk i strapienie, Kraków 2008.

Kurkowska-Budzan M., Informator, świadek historii, narrator - kilka wątków epistemologicznych i etycznych oral history, „Wrocławski Rocznik Historii Mówionej”, R. 1 (2011), s. 9-34.

Lang J., Textual Silence: Unreadability and the Holocaust, New Brunswick-New Jersey 2017.

Mühlhäuser R., Understanding Sexual Violence during the Holocaust: A Reconsideration of Research and Sources, „German History”, t. 39 (1/2020), s. 15-36.

Najnigier B., Powrót z daleka, Warszawa 1973.

Norrick N.R., Humour in Oral History Interviews, „Oral History”, t. 34 (2/2020), s. 85-94.

Ostrowska J., „Panienki”, „szwungi”, „fajfusy”, „laleczki”, [w:] eadem, Oni. Homoseksualiści w czasie II wojny światowej, Warszawa 2021, s. 263-279.

Panichelli-Batalla S., Laughter in Oral Histories of Displacement: „One Goes on a Mission to Solve Their Problems”, „The Oral History Review”, t. 47 (1/2020), s. 73-92.

Ritchie D.A., Doing Oral History. A Practical Guide, Oxford 2015.

Skucha M., Homospołeczność, [w:] Encyklopedia gender. Płeć w kulturze, red. K. Czeczot [et al.], Warszawa 2014, s. 203-206.

Sofsky W., Ustrój terroru: obóz koncentracyjny, Warszawa 2016.

Sommer R., Pipels: Situational Homosexual Slavery of Young Adolescent Boys in Nazi Concentration Camps, „Lessons and Legacies”, t. 11 (2014), red. H. Earl, K. Schleunes, s. 86-103. 
Świerkosz M., Ciała podatne na zranienie. Judith Butler, samozniszczenie i radykalne akty oporu, „Etyka”, nr 57 (2018), s. 69-86.

Timofiejew G., Człowiek jest nagi, Łódź 1960.

Werner A., Zwyczajna apokalipsa. Tadeusz Borowski i jego wizja świata obozów, Warszawa 1981.

Zakrzewski J., A myżyjemy dalej..., Lublin 1977.

Zarachowicz W., Nas nie pożarły płomienie. Radogoszcz-Gusen, Warszawa 1991. 


\section{Summary}

The article is a culture-oriented case study aimed at a critical analysis of threads concerning male homosexuality and the figure of the camp pipel. The subject of the analysis are two oral history narratives by Andrzej Kotarski (given to: usc Shoah Foundation and History Meetings House/the KARTA Center), a former Nazi concentration camp inmate. Attempts by the witness to take up marginalized topics in the camp discourse are set in the context of the current state of research on male wartime sexual violence. The use of the appropriately reformulated category of unreadability by Jessica Lang, the discussion of the role of laughter and the (originating from camp times and memoirs) strategy (originating from camp times and fixed in memoirs) of self-feminization of the male victim reveal a number of cultural and social reasons, due to which both narratives remain incomplete. Nevertheless, they are an invaluable testimony to the camp's homosexual violence and, at the same time, the problems related to its articulation. 